\title{
Developmental Strategies for Utilization Models for Returning Livestock and Poultry Manure to the Land
}

\author{
Jia Wei ${ }^{1,2}$, Zang Jianjun ${ }^{3}$, Zhang Qiang ${ }^{2}$, Li Defa $^{3}$ \\ 1. Institute of Environment and Sustainable Development in Agriculture, Chinese Academy of Agricultural Sciences, Beijing 100081, China \\ 2. State Key Laboratory of Nutrition Resources Integrated Utilization/Kingenta Ecological Engineering Group Co. Ltd., Beijing 100022, China \\ 3. Ministry of Agriculture Feed Industry Centre, College of Animal Science and Technology, China Agricultural University, Beijing 100193, China
}

\begin{abstract}
This paper summarizes the development of various utilization models for returning livestock and poultry manure to farmlands. It analyzes the problems affecting the industrial development of livestock and poultry manure recycling in China, discusses developmental strategies for the next step in this process. In past years, important progress has been made in exploring utilization models for returning livestock and poultry manure to farmlands, and in identifying suitable parameters for the livestock-carrying capacity of such lands, both at home and abroad. However, problems remain, such as nutrient imbalance after combining planting and livestock systems, large nutrient losses, and a lack of reasonable principles for manure application on farmlands. In future, studies should focus on the environmentally friendly return of manure to farmlands and introduce the concept of nutrient management after combining planting and livestock systems. Techniques should be introduced for the collection, storage, and processing of manure; for the return of the manure to farmlands; for reasonable manure application; and for balancing the nitrogen and phosphorus nutrients in order to reduce non-point-source pollution; among other aspects. In addition, policies for the efficient recycling of livestock and poultry manure should be promoted.
\end{abstract}

Keywords: large-scale livestock farms; manure; wastewater; combined planting and livestock systems; nutrients

\section{Introduction}

From 1978 to 2012, the production value of livestock farming in China had increased by 130 times, whereas that of crop farming had increased by 42 times, indicating that the increase in livestock farming had far surpassed that of crop farming [1]. Large-scale livestock farming is an important symbol of modern animal husbandry. In 2014, the scale of intensive livestock farming of pigs $(>500)$, broilers $(>10000)$, and layers $(>2000)$ reached $41.8 \%, 73.3 \%$, and $68.8 \%$, respectively [2]. In 2015 , the scale of intensive livestock farming of dairy cattle $(>100)$, beef cattle $(>50)$, and goats and sheep $(>100)$ was $45.2 \%$, $27.5 \%$, and $36.5 \%$, respectively [3]. According to China's 13 th
Five-Year Plan, by 2020, the scale of intensive livestock farming of slaughtered pigs $(>500)$ and stocked beef cattle $(>100)$ will be $52 \%$ and $60 \%$, respectively, and the overall proportion of intensive livestock farming for animal husbandry will be more than $50 \%$. At present, the proportions of pork, poultry egg, and milk yields in preponderant provinces in China are $92 \%, 68 \%$, and $88 \%$, respectively. With the rapid development of intensive farming, the total amount of livestock manure has continued to increase and become more concentrated. In China, there is a long history of separating crop and livestock farming, which means that the nutrients in livestock and poultry manure cannot be applied in the field effectively. In the short term, the environmental pressure of the livestock industrial region is becoming in-

Received date: June 25, 2017; Revised date: July 15, 2017

Corresponding author: Zang Jianjun, Ministry of Agriculture Feed Industry Centre, College of Animal Science and Technology, China Agricultural University, Associate Professor. Major research field is Swine nutrition and environment. E-mail: zangjj@cau.edu.cn

Funding program: CAE Advisory Project "Several Strategic Issues on Eco-Civilization Construction (Phase II)" (2015-ZD-16); National High-tech Research and Development Program (863 Program) “Development of Key Equipment of Livestock and Poultry Environment Monitoring and Digital Feeding” (2013AA10230602). Chinese version: Strategic Study of CAE 2017, 19 (4): 130-137

Cited item: Jia Wei et al. Developmental Strategies for Utilization Models for Returning Livestock and Poultry Manure to the Land. Strategic Study of CAE, https://doi. org/10.15302/J-SSCAE-2017.04.021 
creasingly intense, and the environmental problems of livestock production are more prominent.

The best way to utilize manure nutrients would be for the waste to be returned to the field in an integrated crop-livestock farming system. The available nitrogen $(\mathrm{N})$, phosphorus $(\mathrm{P})$, and potassium levels in livestock and poultry manure in China are equivalent to approximately $3.602 \times 10^{7} \mathrm{t}$ urea, $1.166 \times 10^{8} \mathrm{t}$ super phosphate, and $2.122 \times 10^{7} \mathrm{t}$ potassium chloride [4,5]. In China, it is estimated that the $\mathrm{N}$ and $\mathrm{P}$ nutrients in livestock and poultry manure are equivalent to $79 \%$ and $57 \%$, respectively, of the amount of fertilizer used in the same period; therefore, the efficient utilization of breeding waste would be significant in reducing the use of chemicals [6]. Substitution with manure would reduce the production and application of chemical fertilizers, avoid the wastage of resources and emission of greenhouse gases [7]. The return of livestock and poultry manure nutrients to the field includes the whole process of livestock breeding, manure collection and storage, and crop use, and nutrient loss varies considerably at each link in the production chain [8,9]. In China, there is a lack of research on manure nutrient management and the rational application of manure in the field. In this paper, the domestic and foreign utilization modes of livestock waste are summarized, the implementation effects of these modes are compared, the developmental strategy of China's green mode on land use of livestock waste is discussed, and some measures and suggestions to carry out related works are put forward.

\section{Modes and mechanisms of livestock waste application to the field from international studies}

\subsection{Main modes in global land uses of livestock waste}

The utilization mode for returning livestock manure to the land is all about the processing of solid and liquid manure, ranging from stabling collection, storage, fermentation processing, transportation, and final land use in the production chains [10]. Common patterns of the model chain for returning livestock waste to the land are shown in Fig. 1.

The Smithfield pig farms mainly adopt the processing method of anaerobic fermentation and pond storage. Pig manure is eventually used as an organic fertilizer in the farmland. Through

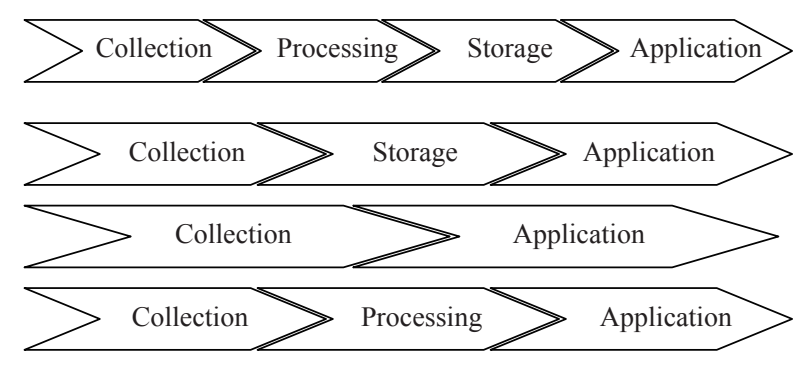

Fig. 1. Model chains of waste breeding for land use. field investigations, the US Department of Agriculture has found that the direct return of livestock and poultry wastes to the field is the main processing mode compared with the mode of livestock manure collection to anaerobic digestion to land use. From the market point of view, a model of biogas production and biogas slurry recovery is more suitable for areas with an abundant manure supply and minimum fertilizer value. The energy technology related to livestock and poultry wastes in the USA has been commercialized for many years, such as incineration plants, anaerobic fermentation, fuel power generation, etc. [11]. Basic information about the disposal of wastes by livestock and poultry farms in the USA is shown in Table 1.

The main mode of livestock and poultry waste use in the UK is the return of manure to the field, such as the manure collection-storage-farmland mode. The methods of storing liquid wastes encompass ground storage tanks, wall-type storage, oxidation ponds, and underground storage tanks. The main application methods of liquid manure are surface broadcasting, banding, shallow injection, deep injection, sprinkling irrigation, etc. $[12,13]$. In Bangladesh, $70 \%-80 \%$ of farmers store solid waste, of which $50 \%$ is used for crop fertilization. Most of Vietnam's large and medium-sized farms have biogas engineering facilities, and $70 \%-90 \%$ of biogas slurry is applied to farmlands or aquaculture. In Argentina, liquid manure is stored in oxidized ponds, $75 \%$ of the solid waste from farms is stored, and $50 \%$ of farm manure is returned to the field. In Costa Rica, $50 \%$ of large-scale dairy farm manure is applied to pastures, whereas most of the pig farms collect and store excrement; $50 \%$ of the pig farms have anaerobic digestion processing equipment [10]. The utilization of livestock and poultry wastes in some countries is shown in Table 2.

\subsection{Mechanisms for the utilization of livestock waste in the USA and Europe}

In the USA, the national strategy for the prevention and control of waste pollution and the national pollution emission reduction license system (National Pollution Discharge Elimination System NPDES) have promoted the research and application of related technologies for comprehensive nutrient management planning [14]. In the US comprehensive nutrient management plan for livestock and poultry manure, large-scale livestock farming must be comprehensively carried out. Voluntary implementation by small farmers is encouraged. On the other hand, the agricultural environment in European Union (EU) countries is protected, and the nutrient management policy plays an important role [15]. In the UK, nutrient management policies aim to promote the utilization of farm waste, reduce the environmental impact of nitrate leaching and greenhouse gases, and encourage the application of manure in accordance with the manure nutrient management plans [12]. In Germany, there is no specific legislation for livestock and poultry waste management and uti- 
Table 1. Basic information on the return of wastes from livestock and poultry farms to the land in the USA.

\begin{tabular}{|c|c|c|c|c|c|}
\hline Livestock farm & Distribution & Setting of farmland & Excrement collection & Crop application & Effect \\
\hline Dairy cows & $\begin{array}{l}\text { Western United States, } \\
\text { California, Idaho, } \\
\text { New Mexico }\end{array}$ & $\begin{array}{l}\text { Sixteen percent of dairy farms not matching } \\
\text { farmland and requiring long-distance } \\
\text { transportation to farms for land use }\end{array}$ & $\begin{array}{l}\text { Manure cleaning by } \\
\text { flooding }\end{array}$ & Corn & $* * *$ \\
\hline Pigs & $\begin{array}{l}\text { North Carolina, } \\
\text { Oklahoma, Utah, } \\
\text { Western United States }\end{array}$ & $\begin{array}{l}\text { Twenty-two percent of the farms not } \\
\text { matching farmland and requiring long- } \\
\text { distance transportation to farms for land use }\end{array}$ & $\begin{array}{l}\text { Manure cleaning by } \\
\text { flooding }\end{array}$ & Corn & $* * *$ \\
\hline Broiler chicken & $\begin{array}{l}\text { Southern United } \\
\text { States }\end{array}$ & $\begin{array}{l}\text { Very few chicken farms supporting use of } \\
\text { manure in the surrounding land }\end{array}$ & Dry collection & Peanut and cotton & $* * *$ \\
\hline
\end{tabular}

*** represents a very good effect of return to the land; ** represents a good effect of return to the land; * represents a modest effect of return to the land.

Table 2. Utilization of livestock and poultry wastes in some countries.

\begin{tabular}{|c|c|c|c|c|c|}
\hline Country & $\begin{array}{l}\text { Livestock and poultry } \\
\text { species }\end{array}$ & Land use modes & Excrement collection & Effect & $\begin{array}{l}\text { Literature } \\
\text { resources }\end{array}$ \\
\hline $\begin{array}{l}\text { United } \\
\text { Kingdom }\end{array}$ & Pigs, cattle, poultry & Manure-storage-farmland & $\begin{array}{l}\text { Manure cleaning by water } \\
\text { submergence, bedding collection }\end{array}$ & $* * *$ & {$[12,13]$} \\
\hline Bangladesh & Chicken, ducks, cows & Manure- storage-farmland & Dry collection & $* *$ & [10] \\
\hline Vietnam & Pigs, cattle, poultry & $\begin{array}{c}\text { Manure-biogas-farmland / } \\
\text { aquaculture }\end{array}$ & Dry collection & $* *$ & [10] \\
\hline Argentina & Beef cattle & Manure-storage-farmland & Dry collection & $* *$ & [10] \\
\hline Costa Rica & Cows, pigs & $\begin{array}{l}\text { Manure-pasture, manure- storage/ } \\
\text { biogas-farmland }\end{array}$ & Manure cleaning by flooding & $*$ & [10] \\
\hline
\end{tabular}

*** represents a very good effect of return to the land; ** represents a good effect of return to the land; * represents a modest effect of return to the land.

lization, but the relevant provisions for pollution prevention and control of breeding waste are integrated into relevant laws and regulations in the area of environmental protection. In Germany, $80 \%$ of farms use the mixed crop-livestock system, such as the manure-anaerobic digestion-farmland mode. Nutrient balance is considered on the basis of the upper limit of crop nutrient demand for $\mathrm{N}$ and $\mathrm{P}[16]$.

The comprehensive manure nutrient management plan adopted in the USA is similar to the EU nutrient management policy. The purpose is to both increase the utilization rate of and reduce the environmental loss of manure nutrients. Both the USA and the EU have enacted laws and regulations to achieve nutrient management, such as that of nitrates and nitrate-sensitive areas, the Water Conservation Law, Bill "590", the Water Purification Law, etc. [17].

Comprehensive manure nutrient management is at the core of nutrient balance, including the supply of manure nutrients, crop $\mathrm{N}$ and $\mathrm{P}$ nutrient demands, and soil nutrient supply levels, in order to reduce the environmental discharge of livestock waste nutrients. The USA and countries in Europe have used the nutrient balance method to characterize the sustainability of the integrated crop-livestock system and to guide the utilization of livestock wastes [18-20]. The application of nutrient balance in the USA and Europe includes the farm balance method, nutrient use efficiency (NUE) method, and soil apparent balance method (Table 3). For improving NUE, the implementation of an integrated manure nutrient management plan will effectively combine environmental protection with manure nutrient management to meet crop nutrient demand, while at the same time also solve the problem of livestock and poultry breeding pollution and promote sustainable agricultural development.

\subsection{Reasonable application of manure to farmlands}

\subsubsection{Manure application recommendation}

The principle of quantitative manure application was recommended in the UK and the USA. The farmland capacity, as a place for the use of livestock and poultry manure, depends on the soil fertility and the influence of harvested grain and straw uptakes [37]. It is especially important to control the amount of manure applied in order to reduce nitrogen volatilization [38]. Because the N/P ratio of manure is about twice that of crops, the level of soil $\mathrm{P}$ will increase when manure is applied to meet the crop $\mathrm{N}$ demand. It is suggested that the amount of $\mathrm{P}$ to be applied be determined according to the crop $\mathrm{P}$ requirement, and that the soil $\mathrm{P}$ level be tested so as to achieve the target of appropriate manure application [39]. The EU's Nitrates Act stipulates $170 \mathrm{~kg} \cdot \mathrm{N} / \mathrm{hm}^{2} \cdot \mathrm{a}$ as the maximum amount of manure that can be applied in a nitrate-sensitive area, which forces livestock farms to transport the surplus manure to other farms for application [14]

\subsubsection{Application method}

The longer the manure is applied on the surface, the greater the nutrient loss caused by irrigation or rainwater runoff and the loss of ammonia volatilization will be. Therefore, mixing manure and topsoil can effectively reduce nutrient loss. Research 
Table 3. Nutrient balance application.

\begin{tabular}{|c|c|c|c|c|c|}
\hline Country & $\begin{array}{l}\text { Soil apparent balance } \\
\text { method }\end{array}$ & $\begin{array}{l}\text { Soil system balance } \\
\text { method }\end{array}$ & $\begin{array}{l}\text { Farm balance } \\
\text { method }\end{array}$ & $\begin{array}{l}\text { Nutrient use efficiency } \\
\text { method }\end{array}$ & $\begin{array}{l}\text { Literature } \\
\text { resources }\end{array}$ \\
\hline $\begin{array}{l}\text { United States of } \\
\text { America }\end{array}$ & 0 & 0 & 1 & 1 & {$[21]$} \\
\hline Holland & 6 & 0 & 8 & 8 & {$[22-29]$} \\
\hline Denmark & 0 & 0 & 1 & 1 & {$[30]$} \\
\hline Germany & 0 & 1 & 1 & 1 & {$[31]$} \\
\hline Italy & 1 & 0 & 1 & 0 & [32] \\
\hline United Kingdom & 1 & 0 & 1 & 0 & [33] \\
\hline Australia & 0 & 0 & 0 & 0 & {$[34]$} \\
\hline Japan & 1 & 0 & 1 & 1 & {$[35]$} \\
\hline Vietnam & 0 & 0 & 0 & 0 & {$[36]$} \\
\hline
\end{tabular}

has shown that deep application is beneficial for reducing ammonia volatilization and the nitrogen runoff loss [40,41]. After broadcasting and band application, the soil tillage can effectively inhibit the volatilization of ammonia and the emission of nitrous oxide [42]. When liquid manure was applied to the soil after spraying, the loss of ammonia by ploughing was found to be $55 \%$ lower than that from no ploughing $[38,43]$. When liquid and solid manure are applied, deep ploughing and immediate coverage are the most effective mitigation techniques [44].

\subsubsection{Application time}

The loss of nitrogen is related to the season. Fertilization should be avoided in the autumn and early winter seasons so as to reduce the nutrient loss and increase nutrient uptake by the crops [45]. In the season of high rate of crop growth, the root system has a strong capacity for nutrient uptake, and the available manure nutrients can be rapidly assimilated by the crops [40].

\section{Developmental status of the mode of returning livestock and poultry waste to the land in China}

\subsection{Mode of returning livestock and poultry wastes to the land}

The integrated crop-livestock system is one of the main methods of livestock and poultry waste treatment in China. It refers to the land uses of waste that has been processed through natural stocking or composting (in the case of solid manure in livestock farms), wastewater, part of solid waste that has been anaerobically fermented or stored in an oxidation pond, biogas as renewable energy, biogas slurry, or manure as crop fertilizers [46].

The pathway of returning manure to the farmland is divided mainly into three categories. The first pattern is livestock farming-storage-farmland; that is, all wastes/manure and sewage are stored, and then all are returned as organic fertilizers directly to land use. The second pattern is livestock farming-biogas-farm- land, in which biogas technology is the core, and the manure and sewage are used as raw materials for anaerobic digestion. Under the condition of oxygen deficit, renewable energy in the forms of biogas and biogas slurry are generated. Biogas is used for fuel or electricity, whereas biogas slurry is used to grow crops. The third pattern is livestock and poultry farming-composting + biogasfarmland. This is the pattern of the waste treatment system, including pretreatment, anaerobic treatment, aerobic treatment, reprocessing, solid-liquid separation, biogas slurry from farmland use, biogas purification, methane storage and utilization, among other parts. The various modes of returning livestock and poultry manure to the land in China are shown in Table 4 [47].

\subsection{Amount of livestock and poultry manure returned to the land}

Few studies have been conducted on manure application recommendations, fertilization methods, application times, etc., and the amount of livestock waste applied to the field is mainly determined by the appropriate land-carrying capacity of livestock. For grains, vegetables, fruit trees, and other agricultural and forestry crops of different production patterns, the amounts of manure $\mathrm{N}$ and $\mathrm{P}$ applied to grain crops and vegetables are larger than those applied to fruit trees $[48,49]$. In the processing mode of solid-liquid separation and anaerobic fermentation of the liquid manure, 32-33, 56-69, and 7-18 stocked pigs' manure can be applied to the grain crops, vegetables, and fruit trees, per hectare of farmland per year, respectively [50]. In the processing mode of direct anaerobic fermentation of the manure, 35-37, 53-67, and 8-17 stocked pigs' manure can be applied to the grain crops, vegetables, and fruit trees, per hectare farmland per year, respectively [51].

\subsection{Problems in the development of utilization modes for returning livestock and poultry wastes to the land in China}

Livestock and poultry wastes in China have not been fully 
Table 4. Modes of returning livestock waste to the land in different regions of China.

\begin{tabular}{|c|c|c|c|c|}
\hline District & Partition & Cropping system & Livestock farming level & Mode of manure return to the farmland \\
\hline Northeast region & $\begin{array}{l}\text { The three northeast provinces of } \\
\text { China, northeast Inner Mongolia, } \\
\text { Daxing Anling area }\end{array}$ & One crop a year & Advanced & Manure-biogas/storage-farmland \\
\hline North China & $\begin{array}{l}\text { Hebei Plain, Huanghuai Plain, } \\
\text { Beijing Suburb }\end{array}$ & Two crops a year & $\begin{array}{l}\text { Developed suburban } \\
\text { animal husbandry }\end{array}$ & Manure-compost + biogas-farmland \\
\hline Northwest region & $\begin{array}{l}\text { Northwest inland oasis, Loess } \\
\text { Plateau }\end{array}$ & $\begin{array}{l}\text { One crop a year of } \\
\text { irrigation area }\end{array}$ & Fast development & $\begin{array}{l}\text { Pigs/cattle-compost + biogas-corn } \\
\text { Pig/cattle-storage-cereals (vegetables, fruits) } \\
\text { Pig/cattle-biogas-cereals/ vegetables/fruits/ } \\
\text { grass }\end{array}$ \\
\hline East China & $\begin{array}{l}\text { Yangtze River Delta intensive } \\
\text { farming area, Jianghuai Plain }\end{array}$ & Two crops a year & High intensification & $\begin{array}{l}\text { Pigs-biogas-rice field/cereals/fruits/ } \\
\text { vegetables/tea/bacteria/ algae } \\
\text { Interaction of rice and duck } \\
\text { Pig-biogas-fish-duck-grass } \\
\text { Manure-biogas + organic fertilizer-forage/ } \\
\text { fruits/vegetables }\end{array}$ \\
\hline $\begin{array}{l}\text { South Central } \\
\text { China }\end{array}$ & $\begin{array}{l}\text { Dongting Lake and Poyang Lake } \\
\text { agricultural area }\end{array}$ & Multiple cropping & Advanced & Manure-biogas-rice/grass \\
\hline Southwest region & $\begin{array}{l}\text { Sichuan Basin, Chengdu Plain, } \\
\text { Yungui Plateau valley basin, } \\
\text { Southern Yunnan valley }\end{array}$ & Two crops a year & $\begin{array}{l}\text { Large amount of manure } \\
\text { production }\end{array}$ & $\begin{array}{l}\text { Symbiotic interaction of rice and fish } \\
\text { Cattle-biogas-farmland } \\
\text { Forage-dairy cattle }\end{array}$ \\
\hline
\end{tabular}

utilized, and the main reasons for the lack of widespread application of the modes for returning such wastes to the land are as follows. First, there are many differences in the livestock industry, lands, crop planting industry, etc. among China and the USA and European countries. With regard to the conditions in China, the livestock industry has been developing for several decades, and livestock waste management has followed up-to-standard discharge in terms of traditional industries. At present, many large-scale farms no longer have the conditions for mixing the crop and livestock systems [52]. Second, there is a lack of planning for the utilization of livestock waste in China. The situation is different from that for the large farms in western developed countries, in that the scale, industrialization, and scientific level of the livestock industry are relatively low in China, resulting in a relatively under-developed livestock waste treatment mode in our country [53]. In addition, the development of the crop planting industry lacks the consideration of effective utilization of livestock and poultry manure in the region, and the indiscriminate use of chemical fertilizers for the purpose of increasing crop production is raising the risk of environmental pollution. Third, there is a lack of manure nutrient management policies and relevant laws and regulations to ensure the utilization of livestock waste. There is no concept of livestock waste management in the USA, only the concept of nutrient management, which is very different from our country [52]. Fourth, the lack of funds is the main obstacle to the construction of facilities for the disposal and utilization of livestock and poultry wastes. Livestock and poultry farming is a small-profit industry. For livestock farms, the construction and operation costs for livestock waste disposal and utilization facilities are very high and often beyond the means of many farmers, which leads to the embarrassing situation that it can be built but cannot be run [14]. Fifth, there is nutrient loss of livestock and poultry wastes from the house to the farmland (Fig. 1). Domestic livestock waste management lacks nutrient management guidance. More studies were carried out on nutrient management of livestock and poultry wastes on the regional scale [54-56]. In order to better utilize nutrient resources and reduce the environmental impact of greenhouse gases such as $\mathrm{CO}_{2}, \mathrm{CH}_{4}$, and $\mathrm{N}_{2} \mathrm{O}$, corresponding measures should be taken to reduce nutrient loss.

\section{Strategic suggestions for increasing the return of livestock and poultry wastes to the land in China}

First, carry out a pilot construction and provide policy guidance. Led by the state department of agriculture and environmental protection, experimentation and project demonstration with respect to returning livestock and poultry wastes to the field should be implemented at large and medium-sized farms under typical environmental conditions. The aims should be to create a policy of replacement subsidies with awards for use of organic manure instead of chemical fertilizers, and to support various actual modes for returning livestock and poultry manure to the land. Intensive livestock farms and the surrounding farmers should be encouraged to form a new type of cooperative farm, with a certain size of land for planting. Livestock and poultry wastes should be applied at the local farmland in order to improve the comprehensive income from agriculture and of the farmers, and to promote the green sustainable development of an integrated crop-livestock system and the construction of an ecological civilization and society. 
Second, increase the investment in science and technology to achieve integrated innovations. In view of the many gaps in research on the utilization modes of livestock and poultry wastes in China, an increase of financial investment into science and technology is suggested as well as an introduction of different forms of social capital. To meet the needs of the related engineering technology and equipment for returning livestock and poultry wastes to the land, several kinds of funds or special projects should be set up. Both basic research and integrated innovations are equally important. Upon the introduction, digestion, attraction, and re-innovation processes, a complete system of industrial technical innovation and comprehensive productivity should be formed as soon as possible. At the same time, there should be strengthening of the original motivation, promotion of the optimization and upgrading of patterns and technologies related to the land return of livestock and poultry manure, and achievement of an innovative type of development. Moreover, the levels of mechanization and treatment efficiency in the different links of manure collection, storage, transportation, and land use should be improved. Combined with crop residue treatment and utilization, we should formulate a relevant standard for organic manure production, test methods, and rules on the application of manure to the farmland for cultivation, which can lay a foundation for the establishment of a standardized mode for returning livestock and poultry manure to the land.

Third, implement livestock manure nutrient management. To break the bottleneck on the return of livestock waste to the land, it is necessary on the one hand to promote the integrated crop-livestock system and circulating utilization as the main body, in order to arouse enthusiasm for manure nutrient management in crop and livestock systems. On the other hand, the state should take the nutrient management policy as the guide, and establish and perfect laws and regulations to support the implementation of nutrient management policy. Promotion of the nutrient management plan should be comprehensive, including land, technology, mechanism, equipment, and choice of regional conditions. In particular, the new livestock farms should actively be encouraged to develop the mode of an integrated crop-livestock system. In the preponderant livestock and poultry breeding areas, large and medium-sized biogas projects should be constructed and return of the biogas slurry to the field carried out in accordance with local conditions. In the pig, cow, and beef cattle breeding preponderant areas, a treatment station for harmless livestock and poultry manure collection should be constructed for large-scale farms or free-range concentrated areas. The collection, storage, and composting of the livestock manure can be done regionally, and then the composted manure can be returned to the local field or transited to a centralized processing center to make organic fertilizer. The implementation of a manure nutrient management plan will not only improve the NUE, but also reduce the harmful effects of greenhouse gas emissions on the environment.

\section{References}

[1] Jia W. Studies on the evaluation of nutrient resources derived from manure and optimized utilization in arable land of China (Doctoral dissertation) [D]. Beijing: China Agricultural University, 2014. Chinese.

[2] Editorial Committee of Yearbook of Animal Husbandry and Veterinary Medicine of China. China animal husbandry and veterinary medicine yearbook, 2015 [M]. Beijing: China Agriculture Press, 2015. Chinese.

[3] The Ministry of Agriculture of the PRC. National animal husbandry development program (2016-2020) [J]. Northern Animal Husbandry, 2016 (24): 35. Chinese.

[4] Yuan Y R. Study on the temporal and spatial distribution of organic wastes and the utilization in farmland in China (Master's thesis) [D]. Beijing: China Agricultural University, 2008. Chinese.

[5] Xu W P, Chen T B, Liu J L, et al. Environmental pollution, comprehensive prevention and control tactics of the scale and intensify poultry farming [J]. Environmental Science, 2004, 25(s1): 105-108. Chinese.

[6] Wang Y. The technology on efficient composting and utilization of livestock manure (Master's thesis) [D]. Wuhan: Huazhong Agricultural University, 2008. Chinese.

[7] Bouwman L, Goldewijk K K, Kw V D H, et al. Exploring global changes in nitrogen and phosphorus cycles in agriculture induced by livestock production over the $1900-2050$ period [J]. Proceedings of the National Academy of Sciences of the United States of America, 2013, 110(52): 20882-20887.

[8] Rufino M C, Rowe E C, Delve R J, et al. Nitrogen cycling efficiencies through resource-poor African crop-livestock systems [J] Agriculture Ecosystems \& Environment, 2006, 112(4): 261-282.

[9] Rufino M C, Tittonell P, Wijk M T V, et al. Manure as a key resource within smallholder farming systems: Analysing farm-scale nutrient cycling efficiencies with the NUANCES framework [J]. Livestock Science, 2007, 112(3): 273-287.

[10] Teenstra E, Vellinga T, Aektasaeng N, et al. Global assessment of manure management policies and practices $[\mathrm{J}]$. Conservation \&Recycling, 2014, 844(4): 229-236.

[11] Macdonald J M, Ribaudo M, Livingston M J, et al. Manure use for fertilizer and for energy [R]. Washington: Economic Research Service, U.S. Department of Agriculture, 2009.

[12] Smith K A, Williams A G. Production and management of cattle manure in the UK and implications for land application practice $[\mathrm{J}]$. Soil Use \& Management, 2016, 32(s1): 73-82.

[13] Smith K A, Brewer A J, Dauven A, et al. A survey of the production and use of animal manures in England and Wales. I. Pig manure [J]. Soil Use \& Management, 2000, 17(2): 124-132.

[14] Tao X P, Dong H M. Research progress on animal waste treatment and recycling technology [J]. Journal of Agricultural Science and Technology, 2017, 19(1): 37-42. Chinese.

[15] Zeng Y T, Xiang Y J, Ma L, et al. The implications of the European Union's nutrient management policies for China [J]. World Agriculture, 2011 (4): 39-43. Chinese.

[16] Liao X D. German livestock waste treatment technology and enlightenment [J]. Chinese Poultry, 2013, 35(3): 2-5. Chinese.

[17] Wang F H, Wang Y F, Ma W Q, et al. Experience and enlighten- 
ment on the nutrient management policies in the European and American countries [J]. Chinese poultry, 2008, 30(4): 57-58. Chinese.

[18] Oenema O, Kros H, Vries W D. Approaches and uncertainties in nutrient budgets: Implications for nutrient management and environmental policies [J]. European Journal of Agronomy, 2003, 20(1): 3-16.

[19] Gerber P J, Uwizeye A, Schulte R, et al. Nutrient use efficiency: A valuable approach to benchmark the sustainability of nutrient use in global livestock production [J]. Current Opinion in Environmental Sustainability, 2014 (s9-10): 122-130.

[20] Petersen S O, Sommer S G, Béline F, et al. Recycling of livestock manure in a whole-farm perspective [J]. Livestock Science, 2007, 112(3): 180-191.

[21] Cela S, Ketterings Q M, Czymmek K, et al. Characterization of nitrogen, phosphorus, and potassium mass balances of dairy farms in New York State [J]. Journal of Dairy Science, 2014, 97(12): 7614-7632.

[22] Oenema J. Transitions in nutrient management on commercial pilot farms in the Netherlands (Doctoral dissertation) [D]. Wageningen: Wageningen University, 2013.

[23] Oenema J, Keulen H V, Schils R L M, et al. Participatory farm management adaptations to reduce environmental impact on commercial pilot dairy farms in the Netherlands [J]. NJAS-Wageningen Journal of Life Sciences, 2011, 58(1-2): 39-48.

[24] Van Bruchem J, Schiere H, Keulen H V. Dairy farming in the Netherlands in transition towards more efficient nutrient use [J]. Livestock Production Science, 1999, 61(2-3): 145-153.

[25] Groot J C J, Rossing W A H, Lantinga E A. Evolution of farm management, nitrogen efficiency and economic performance on Dutch dairy farms reducing external inputs $[\mathrm{J}]$. Livestock Science, 2006, 100(2): 99-110.

[26] Ondersteijn C, Beldman A, Daatselaar C, et al. The Dutch mineral accounting system and the european nitrate directive: Implications for $\mathrm{N}$ and $\mathrm{P}$ management and farm performance [J]. Agriculture Ecosystems \& Environment, 2002, 92(2): 283-296.

[27] Van Keulen H, Aarts H F M, Habekotté B, et al. Soil-plant-animal relations in nutrient cycling: The case of dairy farming system 'De Marke' [J]. European Journal of Agronomy, 2000, 13(2-3): 245-261.

[28] Aarts H F M, Habekotté B, Keulen H V. Phosphorus (P) management in the 'De Marke' dairy farming system [J]. Nutrient Cycling in Agroecosystems, 2000, 56(3): 219-229.

[29] Hilhorst G J, Oenema J, Van K H. Nitrogen management on experimental dairy farm 'De Marke', farming system, objectives and results [J]. NJAS-Wageningen Journal of Life Sciences, 2001, 49(2): 135-151.

[30] Nielsen A H, Kristensen I S. Nitrogen and phosphorus surpluses on Danish dairy and pig farms in relation to farm characteristics [J]. Livestock Production Science, 2005, 96(1): 97-107.

[31] Otten D. Nitrogen and phosphorus management on pig farms in Northwest Germany nutrient balances and challenges for better sustainability [J]. International Journal of Livestock Production, 2013, 4(4): 60-99.

[32] Bassanino M, Grignani C, Sacco D, et al. Nitrogen balances at the crop and farm-gate scale in livestock farms in Italy [J]. Agriculture Ecosystems \& Environment, 2007, 122(3): 282-294.
[33] Cherry K, Mooney S J, Ramsden S, et al. Using field and farm nitrogen budgets to assess the effectiveness of actions mitigating $\mathrm{N}$ loss to water [J]. Agriculture Ecosystems \& Environment, 2012, 147(1): 82-88.

[34] Gourley C J P, Aarons S R, Powell J M. Nitrogen use efficiency and manure management practices in contrasting dairy production systems [J]. Agriculture Ecosystems \& Environment, 2012, 147(1): 73-81.

[35] Kobayashi R, Yamada A, Hirooka H, et al. Changes in the cycling of nitrogen, phosphorus, and potassium in a dairy farming system [J]. Nutrient Cycling in Agroecosystems, 2010, 87(2): 295-306.

[36] Vu T K V, Vu C C, Médoc J M, et al. Management model for assessment of nitrogen flow from feed to pig manure after storage in Vietnam [J]. Environmental Technology, 2012, 33(6): 725-731.

[37] Wang F H, Ma W Q, Dou Z X, et al. The estimation of the production of animal manure and it's environmental effect in China [J] China Environmental Science, 2006, 26(5): 614-617. Chinese.

[38] Zhang H M, Qian Z L, Zhang M K. Environmental risk assessment and prevention measures of farmland manure application $[\mathrm{J}]$. Anhui Agricultural Science Bulletin, 2007, 13(8): 68-69. Chinese.

[39] Satter L D, Hu L, Li L. The dairy phosphorus requirement and it's impact on the environment [J]. Animal Science Abroad, 2001, 28(2): 5-8. Chinese.

[40] Zhu Z L. Loss of fertilizer N from plants-soil system and the strategies and techniques for its reduction $[\mathrm{J}]$. Ecology and Environmental Sciences, 2000, 9(1): 1-6. Chinese.

[41] Zhang Y M, Hu C S, Dong W X. Ammonia volatilization from wheat-maize rotation field in the piedmont of Taihang [J]. Journal of Plant Nutrition and Fertilizer, 2005, 11(3): 417-419. Chinese.

[42] Li X, Ju X T, Zhang L J, et al. Effects of different fertilization modes on soil ammonia volatilization and nitrous oxide emission [J]. Chinese Journal of Applied Ecology, 2008, 19(1): 99-104. Chinese.

[43] Wang C L, Long J L, Zang H W. Study on fertilization methods to reduce ammonia volatilization in the grassland [J]. Technology of Soil and Water Conservation, 2004, (4): 20-21. Chinese.

[44] Webb J, Brian P, Shabtai B, et al. The impacts of manure application methods on emissions of ammonia, nitrous oxide and on crop response-A review [J]. Agriculture Ecosystems \& Environment, 2010; 137(1-2): 39-46.

[45] Shepherd M, Gibbs P, Philipps L. Managing manure on organic farms [R]. Mansfield and Newbury: ADAS Gleadthorpe Research Centre and Elm Farm Research Centre, 2002.

[46] Li D Z, Yang J X. Livestock and poultry waste resource utilization technology-Integrated crop and animal system mode [M]. Beijing: China Agricultural Science and Technology Press, 2016. Chinese.

[47] Gao W S, Chen Y Q, Sui P. Circular agriculture theory and its research methods [M]. Beijing: China Agricultural University Press, 2015. Chinese.

[48]Chen W, Liu D L, Liu J J, et al. Study on livestock carrying capacity based on manure nutrients [J]. Chinese Journal of Animal Science, 2009, 45(1): 46-50. Chinese.

[49] Yang J X, Wang H L, Jiao H C, et al. Stock capacity in different cropping systems [J]. Scientia Agricultura Sinica, 2016, 49(2): 339-347. Chinese.

[50] Sheng J, Sun G F, Zheng J C. Pig farm-cropland configuration 
under typical waste treatment modes - A case study of anaerobic liquid fermentation following solid-liquid separation of waste $[\mathrm{J}]$ Chinese Journal of Eco-Agriculture, 2015, 23(2): 199-206. Chinese.

[51] Sheng J, Sun G F, Zheng J C. Pig farm-cropland configuration under typical waste treatment modes-A case study of direct anaerobic fermentation of manure [J]. Chinese Journal of Eco-Agriculture, 2015, 23(7): 886-891. Chinese.

[52] Liao X D. Comparison of livestock waste management between Europe and the United States, and implications for livestock waste management in China [J]. Chinese Poultry, 2017, 39(4): 1-3. Chinese.

[53] Chang W N, Zhou H P, Gao Y. Balance between crop-planting and livestock-raising: Perspective of agricultural pollution reduction [J]. Journal of Agro-Environment Science, 2013, 32(11): 2118 2124. Chinese.

[54] Hou Y, Gao Z L, Ma W Q, et al. Nitrogen flows in intensive "crop-livestock" production systems typically for the peri-urban area of Beijing [J]. Acta Ecologica Sinica, 2012, 32(4): 1028 1036. Chinese.

[55] Bai Z H, Ma L, Oenema O, et al. Nitrogen and phosphorus use efficiencies in dairy production in China $[\mathrm{J}]$. Journal of Environmental Quality, 2013, 42(4): 990-1001.

[56] Bai Z H, Ma L, Qin W, et al. Changes in pig production in China and their effects on nitrogen and phosphorus use and losses [J]. Environmental Science \& Technology, 2014, 48(21): 12742-12749. 